Article

\title{
Vertical Distribution and Controlling Factors Exploration of Sc, V, Co, Ni, Mo and Ba in Six Soil Profiles of The Mun River Basin, Northeast Thailand
}

\author{
Wenxiang Zhou ${ }^{1}$, Guilin Han ${ }^{1, *} \mathbb{*}$, Man Liu ${ }^{1}\left(\mathbb{D}\right.$, Chao Song ${ }^{2}$, Xiaoqiang $\operatorname{Li}^{1}(\mathbb{D}$ and \\ Fairda Malem ${ }^{3}$ \\ 1 Institute of Earth Sciences, China University of Geosciences, Beijing 10083, China; \\ zhouwenxiang@cugb.edu.cn (W.Z.); Iman@cugb.edu.cn (M.L.); xiaoqli@cugb.edu.cn (X.L.) \\ 2 Institute of Hydrogeology and Environmental Geology, Chinese Academy of Geological Sciences, \\ Shijiazhuang 050061, China; songchao@mail.cgs.gov.cn \\ 3 Environmental Research and Training Center, Department of Environmental Quality Promotion, Klong 5, \\ Klong Luang, Pathumthani 12120, China; mfairda@yahoo.com \\ * Correspondence: hanguilin@cugb.edu.cn; Tel.: +86-10-8232-3536
}

Received: 16 January 2020; Accepted: 4 March 2020; Published: 7 March 2020

check for updates

\begin{abstract}
Exploring the enrichment and controlling factors of heavy metals in soils is essential because heavy metals can cause severe soil contamination and threaten human health when they are excessively enriched in soils. Soil samples (total 103) from six soil profiles (T1 to T6) in the Mun River Basin, Northeast Thailand, were collected for the analyses of the content of heavy metals, including $\mathrm{Sc}, \mathrm{V}, \mathrm{Co}, \mathrm{Ni}, \mathrm{Mo}, \mathrm{Ba}$. The average contents of soil heavy metals decrease in the following order: Ba, V, Ni, Sc, Co, and Mo (T1, T3, T4 and T5); Ni, V, Ba, Co, Sc, Mo, and Ba (T2); Ba, V, Sc, Ni, Mo, and Co (T6). An enrichment factor (EF) and geoaccumulation index were calculated to assess the degree of heavy metal contamination in the soils. The EFs of these heavy metals in most samples range from 0 to 1.5 , which reveals that most heavy metals are slightly enriched. Geoaccumulation indexes show that only the topsoil of T1 and T2 is slightly contaminated by Ba, Sc, Ni, and V. Soil organic carbon (SOC), soil $\mathrm{pH}$ and soil texture are significantly positively correlated with most heavy metals, except for a negative correlation between soil $\mathrm{pH}$ and $\mathrm{Mo}$ content. In conclusion, the influence of heavy metals on soils in the study area is slight and SOC, soil pH, soil texture dominate the behavior of heavy metals.
\end{abstract}

Keywords: soil heavy metals; enrichment factor; geoaccumulation index; Mun River Basin; Northeast Thailand

\section{Introduction}

Soil is a huge sink for heavy metals derived from parent rocks and anthropogenic activities, most of which will cause serious contamination once enriched in soils [1]. Because air, water and rocks interface in soil environment, the heavy metals in soils are transported by various carriers, which may lead to the enrichment of heavy metals in some areas [2-4]. The Mun River Basin is located in Northeast Thailand, which is one of the largest agricultural regions in Thailand [5]. The enrichment of toxic heavy metals will lower soil fertility and increase the input of these heavy metals to the food chain, which may be adverse to human health [2]. Therefore, it is highly significant to study the distribution characteristics of heavy metals in the Mun River Basin.

The heavy metals $\mathrm{Co}, \mathrm{Ni}, \mathrm{Ba}$ and $\mathrm{V}$ are considered as important indicators of soil toxicology, variability in soil composition and human health risks [6]. With the urbanization and industrialization in the Mun River Basin, these heavy metals are frequently emitted out from tire abrasion, industrial 
production, and fertilizer application and can easily accumulate in soils [6]. The Mun River Basin is an important agricultural region in Thailand and large amounts of fertilizers are used, so soils in the basin are easily polluted, making it essential to explore the distributions of these heavy metals in soil profiles. Scandium (Sc) has drawn great attention due to its potential contamination to the environment and the risks to cause various diseases with its wide application in medicine and technology [7], so it is significant to explore the potential pollution of Sc emitted out from factories and hospitals across the basin. In the last three decades, considerable urbanization and industrialization have occurred in Thailand, which may cause soil contamination of these heavy metals by the combustion of fossil fuel, emission of vehicle exhaust, etc. [6,8]. Although the concentrations of molybdenum (Mo) are usually quite low in soils and rocks, Mo is essential for plants, animals and humans [9]. Relative to soil contamination problems, Mo deficiency has attracted more attention because it will largely reduce crop yield [10]. Mo deficiency in the crops grown in Northeast Thailand has been reported, making it necessary to study the distribution of Mo there [11,12]. Moreover, as the most important agricultural region in Thailand, heavy metal contamination or deficiency would affect human health through the food chain. Therefore, these six heavy metals ( $\mathrm{Sc}, \mathrm{V}, \mathrm{Co}, \mathrm{Ni}, \mathrm{Mo}, \mathrm{Ba})$ were selected to help to assess the soil condition and provide the basis for the strategies of agricultural management.

The mobility of soil heavy metals is controlled by various factors, such as soil $\mathrm{pH}$, soil organic matter (SOM) and soil texture [2,13]. Generally, the more mobile heavy metals are, the more available they are for plants, which increases the risk that they enter the food chain of humans. The relationships between these heavy metals and soil properties may vary with different soil conditions, for example, the adsorption of Mo on clay is regulated by soil $\mathrm{pH}$ [9]. It is therefore necessary to explore the relationships between heavy metals and soil properties to better understand the distributions of these heavy metals. This study aims to: (1) learn about the spatial distributions of these heavy metals in six soil profiles; (2) assess the risks of soil heavy metal contamination; and (3) explore the controlling factors of soil heavy metal behaviors.

\section{Materials and Methods}

\subsection{Study Area}

This study was conducted in the Mun River Basin, the largest river basin $\left(82,000 \mathrm{~km}^{2}\right)$ in Northeast Thailand $\left(14^{\circ} 00^{\prime} \sim 16^{\circ} 00^{\prime} \mathrm{N}, 101^{\circ} 30^{\prime} \sim 105^{\circ} 30^{\prime} \mathrm{E}\right)$. The Mun River Basin, of which the elevation ranges from 100 to $1065 \mathrm{~m}$ (Figure 1), is dominated by a tropical savanna climate which leads to a dry season and a rainy season all year round [14]. Most crops are cultivated during the rainy season (April to November) when $85 \%-90 \%$ of the annual precipitation falls [15]. Alluvial and sandy soils in the basin are heavily leached and have low organic matter contents, leading to the frequent use of fertilizers $[15,16]$. Land cover types are various in the basin, including crops, forest, grass, water, etc., and most forest lands are distributed near the southwestern and southeastern border of the basin (Figure 1). In the Mun River Basin, shale, siltstone, sandstone, and conglomeritic sandstone are the main rock types of the rock basement which is covered by the Quaternary alluvial sediment [17].

\subsection{Sampling and Analysis}

Soil samples (total 103) were collected in March 2018, from six soil profiles in the Mun River Basin. These soil profiles were dug on paddy lands (T1, T3), forest lands (T2, T6), wetlands (T4) and built-up lands (T5), respectively. Soil samples were collected at intervals of $10 \mathrm{~cm}$ and the number of soil samples was $22,5,10,20,41$, and 5 in the six soil profiles, respectively. These soil profiles are chosen because they are under the main land-use types in the Mun River Basin and are distributed across the basin (Figure 1). The distribution of heavy metals in these profiles would reflect the general condition of heavy metals in the Mun River Basin. These soil profiles are described in detail in Table 1. 
(a)
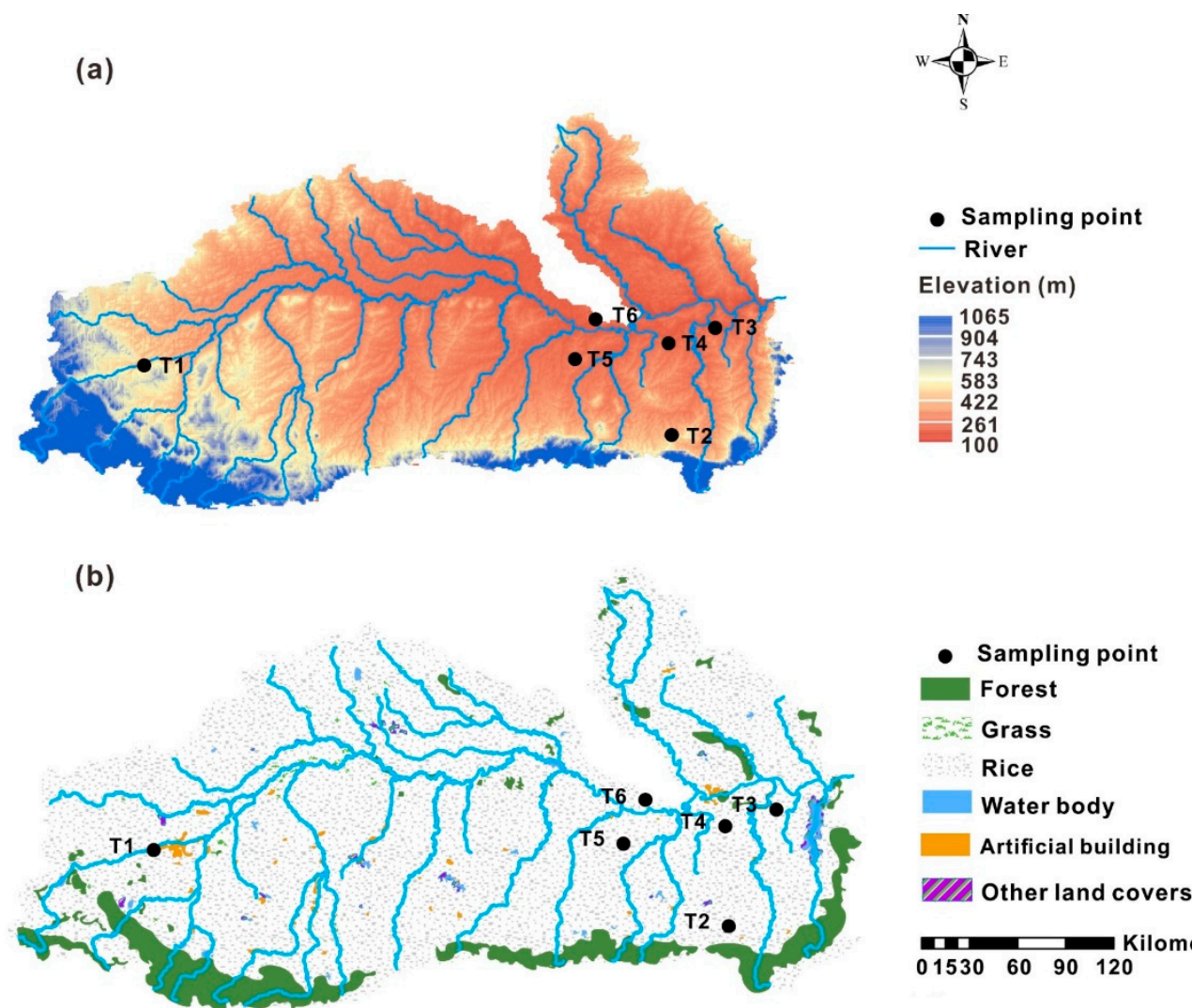

Kilometers

$01530 \quad 60 \quad 90 \quad 120$

Figure 1. Map of elevation (a) and land cover types (b) in the Mun River Basin (Data of elevation come from the website: https://opentopography.org/start).

Table 1. General description of the sampling information.

\begin{tabular}{|c|c|c|c|}
\hline Sampling Point & Land Cover & Depth $(\mathrm{cm})$ & Field Description \\
\hline $\mathrm{T} 1$ & Crop & 220 & Relatively uniform at all depths \\
\hline $\mathrm{T} 2$ & Oak forest & 50 & Compact soil; brown red \\
\hline T3 & Crop & 100 & $\begin{array}{c}0-12 \mathrm{~cm} \text { : Black root layer } \\
12-100 \mathrm{~cm} \text { : Fine silt } \\
>100 \mathrm{~cm} \text { : Iron manganese nodules }\end{array}$ \\
\hline $\mathrm{T} 4$ & Grass & 193 & $\begin{array}{c}0-20 \mathrm{~cm} \text { : Root layer } \\
20-112 \mathrm{~cm} \text { : Fine silt } \\
112-180 \mathrm{~cm} \text { : Weathering crust } \\
180-193 \mathrm{~cm} \text { : Gray and green sand } \\
>193 \mathrm{~cm} \text { : Bedrock }\end{array}$ \\
\hline T5 & Artificial building & 405 & $\begin{array}{c}0-105 \mathrm{~cm} \text { : Fine silt } \\
105-205 \mathrm{~cm} \text { : Iron manganese nodules } \\
205-405 \mathrm{~cm} \text { : Clay layer }\end{array}$ \\
\hline T6 & Forest & 50 & Fine silt \\
\hline
\end{tabular}

Soil samples were air-dried at $25{ }^{\circ} \mathrm{C}$ and unwanted materials such as stones and plant roots were removed by passing soil samples through a $2 \mathrm{~mm}$ sieve [18,19]. Soil samples were ball milled thoroughly to pass a 200-mesh sieve $(<75 \mu \mathrm{m})$ with the Retsch MM400 (Retsch GmbH, Haan, Germany), a widely used grinding machine [20]. $100 \mathrm{mg}$ soil powders were digested in Teflon beakers using ultra-pure $\mathrm{HNO}_{3}(70 \%)$ and ultra-pure $\mathrm{HF}(40 \%)(3: 1)$ at $120^{\circ} \mathrm{C}$ for seven days [21]. If some organic solid residue remains undissolved, aqua regia $\left(\mathrm{HNO}_{3}: \mathrm{HCl}, 1: 3\right)$ would be used to remove organic matters. When all samples were dissolved, the digestion process was repeated twice using $50 \mathrm{ml}$ 
ultra-pure $\mathrm{HNO}_{3}(70 \%)$ to break down potential fluorine compounds [21]. After these treatments, the prepared samples were diluted in ultra-pure $\mathrm{HNO}_{3}(2 \%)$ of about $50 \mathrm{ml}$. Finally, the concentration of the heavy metals $\mathrm{Co}, \mathrm{Ni}$ and Mo were measured by ICP-MS (Elan DRC-e, Perkin Elmer, Waltham, MA, USA) and the concentrations of the heavy metals $\mathrm{Ba}, \mathrm{Sc}, \mathrm{V}$ and Ti were measured by ICP-OES (Optima 5300DV, Perkin Elmer, Waltham, MA, USA).

\subsection{Data Treatment}

The enrichment factor $(\mathrm{EF})$ index and the geoaccumulation index $\left(I_{g e o}\right)$ are two important methods to assess the enrichment and contamination of heavy metals in soils [22,23]. The upper continental crust (UCC) is usually chosen as the reference material for the calculation of both indexes [1]. All background values were provided by Wedepohl [24].

For the enrichment factor, Ti was used as a reference element due to its characteristic of low occurrence variability [25]. The enrichment factor was calculated according to the following formula $[26,27]$ :

$$
\mathrm{EF}=([\mathrm{M}] /[\mathrm{Ti}])_{S} /([\mathrm{M}] /[\mathrm{Ti}])_{\mathrm{UCC}},
$$

where $\mathrm{M}$ represents heavy metal concentrations and $\mathrm{S}$ refers to soil samples.

Based on the EF values, the enrichment of heavy metals can be categorized into five grades: minimal enrichment $(\mathrm{EF} \leq 2)$; moderate enrichment $(2<\mathrm{EF}<5)$; significant enrichment $(5 \leq \mathrm{EF}<20)$; high enrichment $(20 \leq \mathrm{EF}<40)$; and extremely high enrichment $(\mathrm{EF} \geq 40)$ [28].

The geoaccumulation index was calculated as follows [29]:

$$
I_{\text {geo }}=\log _{2}\left(\mathrm{C}_{\mathrm{n}} / 1.5 \mathrm{~B}_{\mathrm{n}}\right) \text {, }
$$

where $C_{n}$ represents the concentration of the heavy metal $n$ in soil samples; $B_{n}$ represents the concentration of the heavy metal $\mathrm{n}$ in reference material (UCC); and the factor 1.5 is used to eliminate the lithogenic effects [1]. According to the $I_{g e o}$ values, soil contamination can be categorized into seven classes from uncontaminated $\left(I_{g e o}<0\right)$ to very highly contaminated $\left(I_{g e o}>5\right)$ [22].

\subsection{Statistical Analysis}

In this study, Pearson correlation analysis was applied to analyze the relationship between SOC, soil $\mathrm{pH}$, clay and soil heavy metals. Principal component analysis (PCA) was applied to identify the sources of soil heavy metals. All mathematical analyses were done by SPSS 20 (Statistical Package for Social Science, IBM, Armonk, NY, USA). Figure 1 was produced by ArcMap 10.0 software and other figures were produced by OriginPro 9.0 software (OriginLab Corporation, Northampton, MA, USA).

\section{Results and Discussion}

\subsection{Contents of Heavy Metals in Soil}

The profile distributions of six heavy metals ( $\mathrm{Sc}, \mathrm{V}, \mathrm{Co}, \mathrm{Ni}, \mathrm{Mo}, \mathrm{Ba})$ in six profiles under four land-use types are shown in Figure 2. The average contents of heavy metals in samples from soil profiles T1, T3, T4 and T5 decrease in the following sequence: $\mathrm{Ba}>\mathrm{V}>\mathrm{Ni}>\mathrm{Sc}>\mathrm{Co}>\mathrm{Mo}$ (Table 2). In soil profiles $\mathrm{T} 2$ and $\mathrm{T} 6$, these contents are in the following sequences respectively: $\mathrm{Ni}>\mathrm{V}>\mathrm{Ba}>\mathrm{Co}>$ $\mathrm{Sc}>\mathrm{Mo}$ and $\mathrm{Ba}>\mathrm{V}>\mathrm{Sc}>\mathrm{Ni}>\mathrm{Mo}>\mathrm{Co}$ (Table 2). 

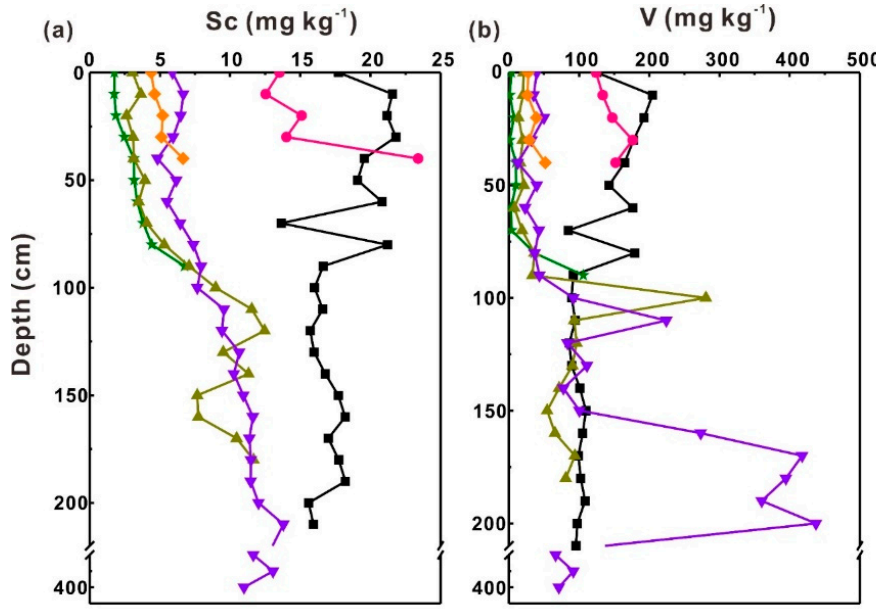

(c) $\quad \mathrm{Co}\left(\mathrm{mg} \mathrm{kg}^{-1}\right)$
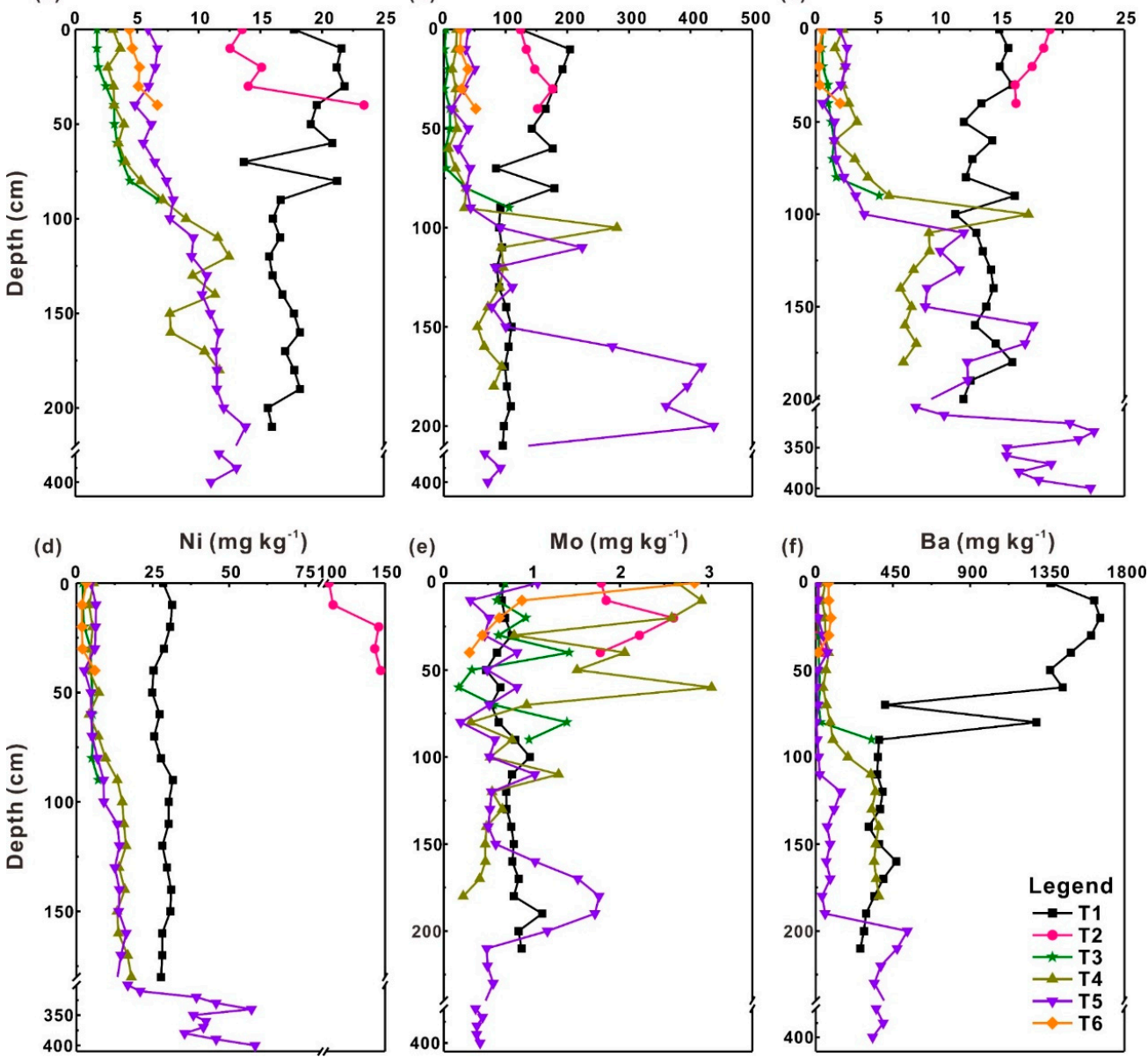

Figure 2. Vertical distributions of heavy metals, including Sc (a), V (b), Co (c), Ni (d), Mo (e) and Ba (f). (Some data were omitted because of their small variation ranges).

Table 2. Statistical results for heavy metal contents $\left(\mathrm{mg} \mathrm{kg}^{-1}\right)$ of soil samples from six soil profiles.

\begin{tabular}{cccccccc}
\hline Soil Profile & Item & Sc & $\mathbf{V}$ & $\mathbf{C o}$ & $\mathbf{N i}$ & $\mathbf{M o}$ & Ba \\
\hline T1 & Min & 13.65 & 84.65 & 11.30 & 24.76 & 0.48 & 259.62 \\
& Max & 21.82 & 204.50 & 16.12 & 31.58 & 1.12 & 1659.68 \\
& Mean (SD) & $17.95(2.27)$ & $123.47(39.68)$ & $13.70(1.50)$ & $28.58(1.97)$ & $0.75(0.14)$ & $764.44(561.23)$ \\
T2 & Min & 12.54 & 124.26 & 16.15 & 102.61 & 1.77 & 8.41 \\
& Max & 23.40 & 176.18 & 18.98 & 146.22 & 2.61 & 49.94 \\
& Mean (SD) & $15.72(4.39)$ & $146.64(19.79)$ & $17.47(1.28)$ & 128.15 & $2.05(0.36)$ & $20.62(16.79)$ \\
& Min & 1.76 & 1.26 & 0.49 & $2.05)$ & 0.17 & 12.57 \\
T3 & Max & 6.76 & 105.87 & 5.15 & 7.14 & 1.42 & 324.63 \\
& Mean (SD) & $3.26(1.53)$ & $18.22(32.50)$ & $1.45(1.36)$ & $4.41(1.66)$ & $0.77(0.41)$ & $48.62(97.07)$ \\
T4 & Min & 2.63 & 7.64 & 1.55 & 4.10 & 0.22 & 37.43 \\
& Max & 12.46 & 280.59 & 17.23 & 18.00 & 3.04 & 367.81 \\
& Mean (SD) & $6.89(3.52)$ & $59.75(62.29)$ & $5.78(3.89)$ & $10.72(5.10)$ & $1.19(0.97)$ & $188.94(142.42)$ \\
T5 & Min & 4.83 & 12.72 & 0.55 & 2.53 & 0.19 & 2.75 \\
& Max & 13.88 & 437.43 & 22.55 & 58.55 & 1.76 & 534.58 \\
& Mean (SD) & $10.45(2.67)$ & $111.98(107.71)$ & $10.05(6.45)$ & 18.35 & $0.65(0.36)$ & $202.71(171.92)$ \\
T6 & Min & 4.38 & 26.37 & 0.24 & $15.25)$ & 0.80 & 13.86 \\
& Max & 6.66 & 51.76 & 1.97 & 6.01 & 2.85 & 89.26 \\
& Mean (SD) & $5.19(0.89)$ & $34.75(10.79)$ & $0.67(0.74)$ & $2.98(1.81)$ & $1.02(1.05)$ & $65.37(29.51)$ \\
\hline
\end{tabular}

Vertically, the contents of heavy metals generally increase with depth in most soil profiles, excluding profile $\mathrm{T} 1$, which is quite marked in Sc, V, and Co (Figure 2). Most rainfall in the study 
area is mainly concentrated in the rainy season [15], which causes a large amount of precipitation in a short period and results in severe leaching of heavy metals down these soil profiles [30]. The vertical distributions of heavy metal concentrations can reflect the relative mobility of these metals in soil profiles [3]. Based on the distribution characteristics of these heavy metals in the six profiles (Figure 2), it can be concluded that the mobility of heavy metals Sc, V, and Co is higher than the mobility of $\mathrm{Ni}, \mathrm{Mo}$, and $\mathrm{Ba}$ in these soil profiles. Soil profile $\mathrm{T} 1$ is dug in rice fields where fertilizer is frequently used. The higher concentrations of these heavy metals in the topsoil of profile T1 are caused by the applications of pesticide and fertilizer [23]. Huge positive peaks of heavy metal concentrations (V, Co, Mo) in soil profile T5 were observed at approximately $165-200 \mathrm{~cm}$ depth. According to the field recordings, there is a layer of iron-manganese oxides at 160-205 cm depth, where these positive peaks occur (Table 1). The phenomenon is attributed to the adsorption of iron-manganese oxides on these heavy metals [31,32]. Due to the surface complex formation and the existence of specific adsorption potentials, iron-manganese oxides own a relatively strong ability to absorb and concentrate heavy metals in soils [31,33]. However, heavy metals Sc, Ni and Ba do not show positive peaks of concentrations in that layer, indicating that the influence of iron-manganese oxides on these heavy metals is limited. Potential reasons behind the phenomenon need to be further explored.

\subsection{Assessment of Soil Heavy Metal Contamination}

\subsubsection{Enrichment of heavy metals}

The calculated EF factor values of most samples are lower than 2 (Figure 3), which indicates the minimal enrichment of these heavy metals in soils [28]. Several extremely abnormal EF values occur in soil profile T5, exactly at the depth where abnormal heavy metal concentrations appear (Figure 2), which can be attributed to the absorption by iron-manganese oxides. The sources of heavy metals in soil profiles comprise crustal materials (e.g. parent rocks) and non-crustal materials (e.g. anthropogenic sources). Due to lithogenic effects, an $\mathrm{EF}$ value $=1.5$ is regarded as an important threshold for assessing whether human activities influence heavy metal concentrations in soils [34]. Except for the V in the soil profile T5 and Mo in the soil profile T6, the average EF values of these heavy metals in different soil profiles are lower than 1.5 which indicates that these heavy metals are mainly derived from natural processes [23,35]. The EF values of V (2.2) and Mo (1.8) in soil profiles T5 and T6 are higher than 1.5 , indicating that non-crustal materials are also important contributors for these heavy metals [35]. The EF values of Mo in soil profile T1 that was dug in paddy fields are lower than 0.5 which shows that the Mo deficiency may have occurred in local agricultural lands. Molybdenum fertilizer may be a good choice to make up the Mo deficiency in local agricultural lands [11].
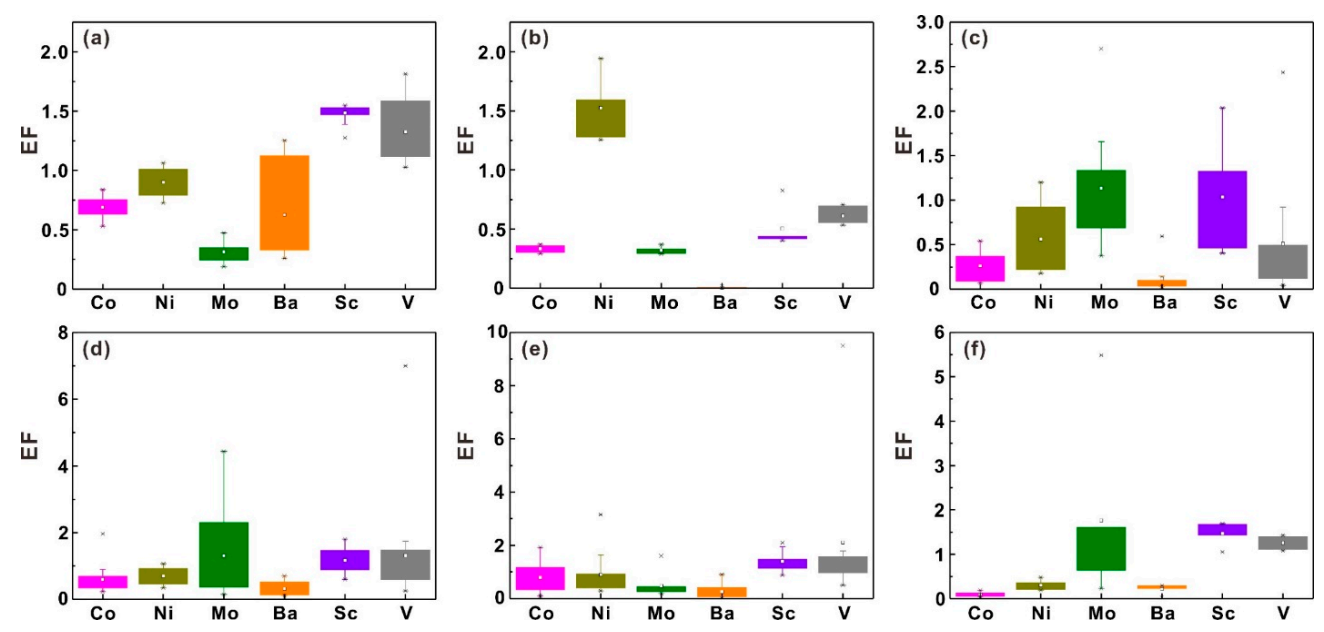

Figure 3. Box plots of heavy metal EF values in six soil profiles, including soil profiles T1 (a), T2 (b), T3 (c), T4 (d), T5 (e) and T6 (f). 


\subsubsection{Contamination Assessment by $I_{\text {geo }}$ Values in Topsoil.}

Heavy metal contamination was reported to be most obvious in topsoil $(0-40 \mathrm{~cm})$ [36], so the contamination assessment should be concentrated on topsoil. The $I_{\text {geo }}$ values of these heavy metals in topsoils $(0-10,10-20,20-30,30-40 \mathrm{~cm})$ of six soil profiles are presented in Figure 4 . These values of most metals are lower than 0 at all depths of all soil profiles, except for $\mathrm{Sc}$ and $\mathrm{V}$ in soil profiles $\mathrm{T} 1$ and T2 (Figure 4). The results show that the soils of the six soil profiles are not polluted by these heavy metals in the course of human activities. The positive $I_{\text {geo }}$ values of heavy metals mainly occur in the topsoil of soil profiles T1 and T2, which are located in a paddy field and oak forest, respectively. The $I_{\text {geo }}$ values of $\mathrm{Ba}$ and $\mathrm{Sc}$ in profile $\mathrm{T} 1$ and $\mathrm{Ni}, \mathrm{Sc}$, and $\mathrm{V}$ in profile $\mathrm{T} 2$ are roughly in the range of $0-1$, indicating that the topsoil of these two soil profiles is slightly polluted by these heavy metals. Except for the surface soil layer $(0-10 \mathrm{~cm})$, the $I_{\text {geo }}$ values of $V$ are in the range of 1-2, indicating the moderate contamination of $\mathrm{V}$ in the topsoil of soil profile T1. Heavy metals that may be adverse for human health, such as $\mathrm{Ni}$ and $\mathrm{V}$, have been reported to accumulate in soils accompanied by the frequent application of fertilizers [37], so a potential reason for the contamination is the application of fertilizers. Chemical fertilizers cause heavy metal pollution by directly inputting various heavy metals into soils, while organic fertilizers enhance heavy metal pollution levels by forming complexes with heavy metal ions.
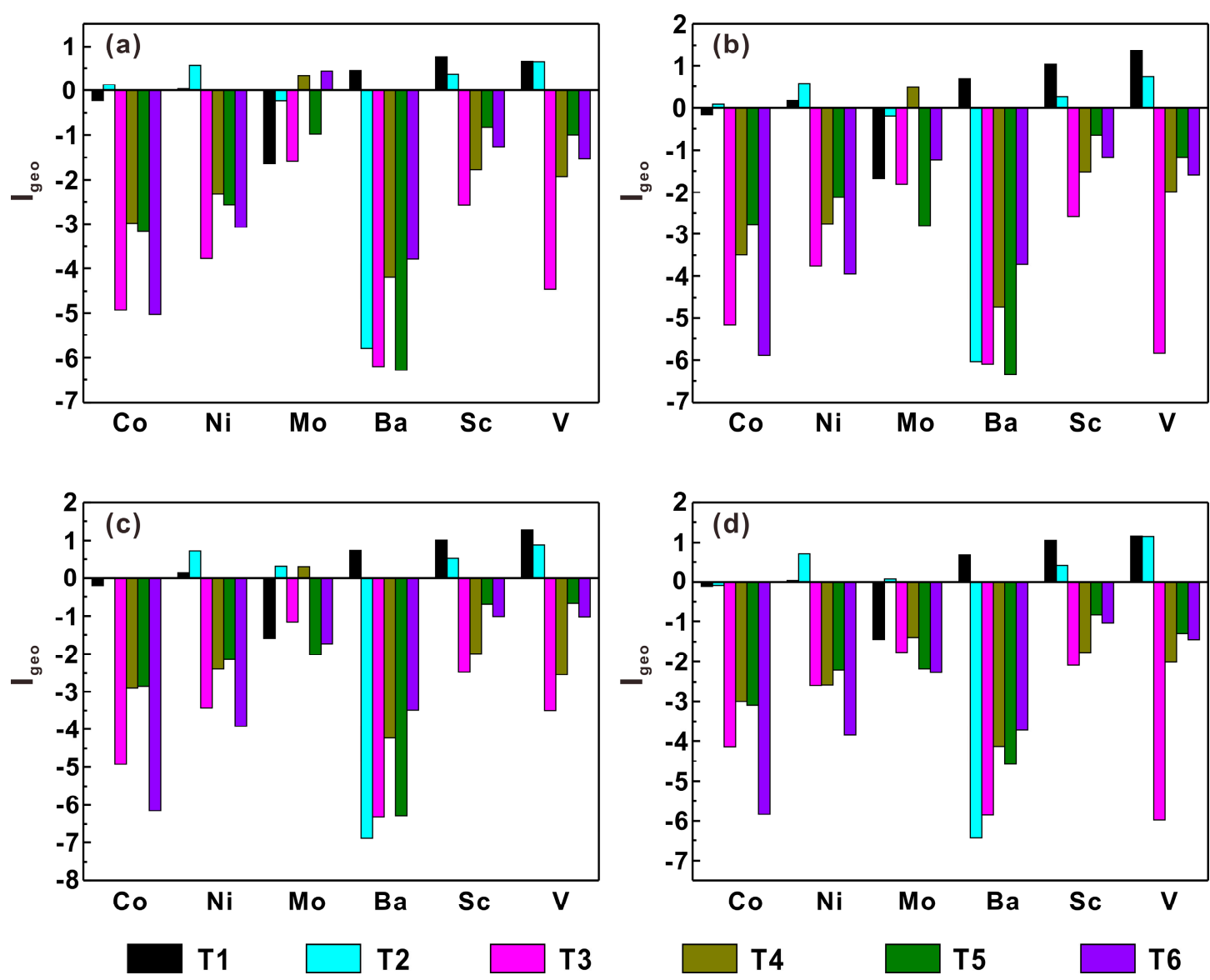

Figure 4. Geoaccumulation indexes of heavy metals in the surface layers of six soil profiles. $0-10 \mathrm{~cm}(\mathbf{a})$; $10-20 \mathrm{~cm} \mathrm{(b);} \mathrm{20-30} \mathrm{cm} \mathrm{(c);} \mathrm{30-40} \mathrm{cm} \mathrm{(d).}$

\subsection{Correlation Analysis Between Soil Heavy Metals and Soil Properties.}

\subsubsection{Characteristics of Inter-element Relationships}

The results of Pearson correlation analysis between soil heavy metals and the three soil properties (SOC, soil pH and clay contents) are presented in Table 3. The inter-element relationships show that all 
heavy metals are closely correlated $(P<0.01, P<0.05)$ (except for Mo-Co, Mo-Sc, Mo-V and Ba-Ni), which indicates that the heavy metals $\mathrm{Co}, \mathrm{Ni}, \mathrm{Ba}, \mathrm{Sc}$ and $\mathrm{V}$ are derived from similar natural processes and have similar geochemical behavior [23,38]. The reason Mo is distinct from other heavy metals may be that Mo usually forms oxyanions but not cations in soil and rarely coordinates with ligands such as $\mathrm{OH}^{-}$and $\mathrm{Cl}^{-}$like most heavy metals [39].

Table 3. Correlation analysis between heavy metals and soil properties.

\begin{tabular}{cccccccccc}
\hline & Co & Ni & Mo & Ba & Sc & V & SOC & pH & Clay \\
\hline Co & 1 & $0.652^{* *}$ & -0.063 & $0.419^{* *}$ & $0.763^{* *}$ & $0.558^{* *}$ & $0.298^{* *}$ & $0.451^{* *}$ & $0.739^{* *}$ \\
$\mathrm{Ni}$ & $0.652^{* *}$ & 1 & $0.270^{* *}$ & 0.083 & $0.510^{* *}$ & $0.248^{*}$ & $0.407^{* *}$ & 0.003 & $0.530^{* *}$ \\
$\mathrm{Mo}$ & -0.063 & $0.270^{* *}$ & 1 & $-0.239^{*}$ & $-0.155^{*}$ & 0.115 & $0.329^{* *}$ & $-0.223^{*}$ & -0.064 \\
$\mathrm{Ba}$ & $0.419^{* *}$ & $0.083^{* *}$ & $-0.239^{*}$ & 1 & $0.701^{* *}$ & $0.321^{* *}$ & $0.360^{* *}$ & $0.225^{*}$ & $0.575^{* *}$ \\
$\mathrm{Sc}$ & $0.763^{* *}$ & $0.510^{* *}$ & -0.155 & $0.701^{* *}$ & 1 & $0.517^{* *}$ & $0.414^{* *}$ & $0.378^{* *}$ & $0.897^{* *}$ \\
$\mathrm{~V}$ & $0.558^{* *}$ & $0.248^{*}$ & $0.115^{* *}$ & $0.321^{* *}$ & $0.517^{* *}$ & 1 & 0.159 & $0.365^{* *}$ & $0.543^{* *}$ \\
$\mathrm{SOC}$ & $0.298^{* *}$ & $0.407^{* *}$ & $0.329^{* *}$ & $0.360^{* *}$ & $0.414^{* *}$ & 0.159 & 1 & $-0.298^{* *}$ & $0.433^{* *}$ \\
$\mathrm{pH}$ & $0.451^{* *}$ & $0.003^{* *}$ & $-0.223^{*}$ & $0.225^{*}$ & $0.378^{* *}$ & $0.365^{* *}$ & $-0.298^{* *}$ & 1 & $0.357^{* *}$ \\
Clay & $0.739^{* *}$ & $0.530^{* *}$ & -0.064 & $0.575^{* *}$ & $0.897^{* *}$ & $0.543^{* *}$ & $0.433^{* *}$ & $0.357^{* *}$ & 1 \\
\hline \multicolumn{8}{c}{ Correlation is significant at the 0.05 level. ** Correlation is significant at the 0.01 level }
\end{tabular}

\subsubsection{Influence of Soil Organic Matter on Heavy Metals}

The mobility of heavy metals is reported to be controlled by the process of adsorption and desorption in soils, which is affected by some soil properties such as soil organic matter, soil pH and clay contents $[13,40,41]$. Soil organic matter can be converted into SOC contents with a conversion factor, making SOC contents an important measurement for SOM [42]. Except for V, these heavy metals are significantly positively correlated with SOC contents $(P<0.01)$, indicating that organic matter benefits the accumulation of heavy metals (Figure 5). The heavy metal V occurs in various oxidation states (II, III, IV, or V), and mainly exists as $\mathrm{V}^{5+}$ under weathering conditions [9]. Because SOM is equipped with numerous negatively charged groups, it owns a strong ability to absorb heavy metal divalent and trivalent cations [21]. From this perspective, the weak relationship between V and SOC contents can be explained by the higher valence. However, while the main oxidation states of Mo in the lithosphere are Mo(IV) and Mo(VI), Mo is still closely correlated with SOC contents $(P<0.01)$. The phenomenon may demonstrate that Mo is stabilized by organic matter in a different mechanism, such as complexing with catechol groups of tannin-like compounds in soil organic matter [43].
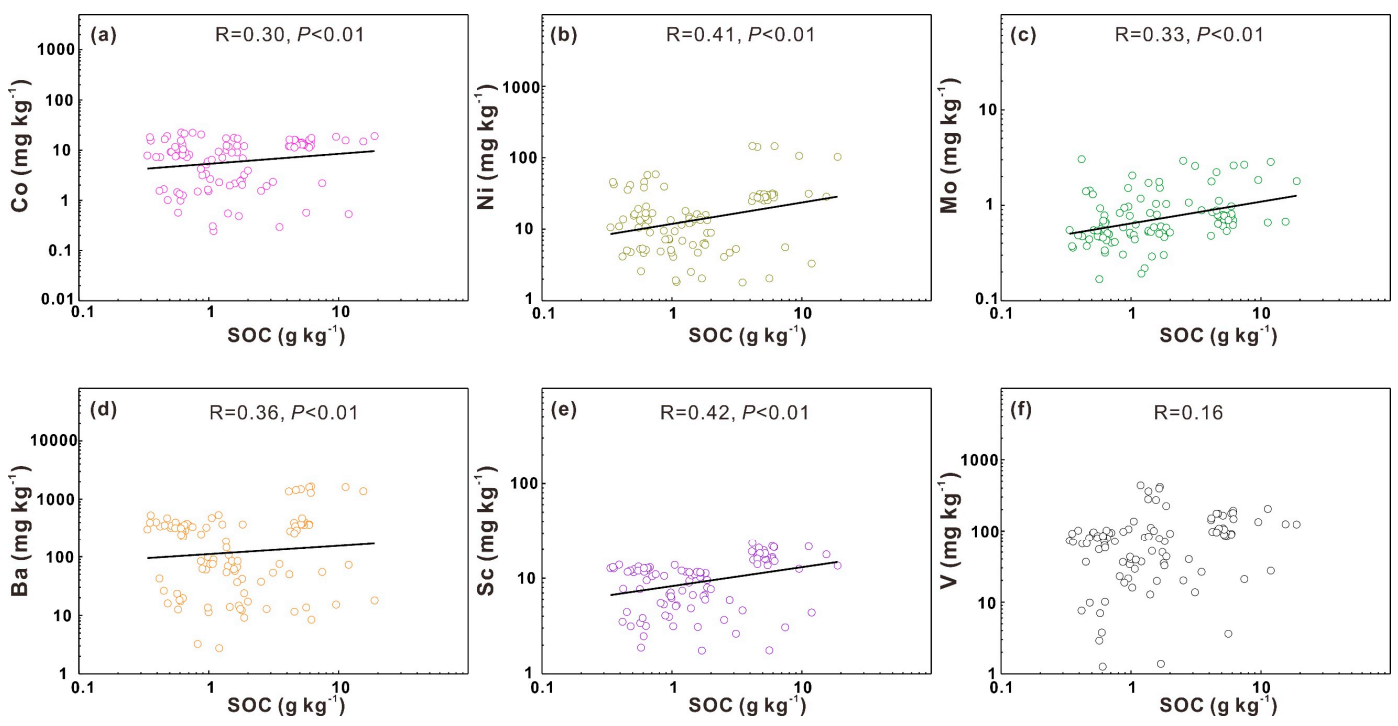

Figure 5. Linear correlation between soil organic carbon (SOC) and the heavy metals Co (a), Ni (b), Mo (c), Ba (d), Sc (e), V (f). 


\subsubsection{Influence of Soil $\mathrm{pH}$ on Heavy Metals}

Soil $\mathrm{pH}$ is widely regarded as the most important factor influencing the mobility and solubility of soil heavy metals $[13,44]$. Except for $\mathrm{Ni}$, all heavy metals are significantly influenced by soil $\mathrm{pH}$ $(P<0.01$ for $\mathrm{Co}, \mathrm{Sc}$, and V; $P<0.05$ for Mo and Ba) (Figure 6). Soil heavy metals Co, Sc, Ba and V are positively correlated with soil $\mathrm{pH}$ while $\mathrm{Mo}$ is negatively correlated with soil $\mathrm{pH}$. The positive relationship between heavy metals and soil $\mathrm{pH}$ has been widely reported $[9,13,23]$. Soil $\mathrm{pH}$ regulates heavy metal contents by changing the available heavy metal contents [45,46]: higher $\mathrm{pH}$ means more $\mathrm{OH}^{-}$existing in soil environment, which would increase the fixation of most heavy metals and reduce the amount of heavy metals uptake by plants, thus benefitting the accumulation of heavy metals. The existing form of Mo in soils results in the negative correlation between Mo and soil pH: Mo always forms oxyanions instead of cations like most heavy metals [9]. In this case, Mo is more available and mobile under higher $\mathrm{pH}$ conditions which corresponds to the negative relationship between Mo and soil $\mathrm{pH}$. The soil $\mathrm{pH}$ values of these samples are in the range of 5.6-7.2 for most samples (around $75 \%$ ) [47]. The heavy metal $\mathrm{Ni}$ is reported to be most sensitive to soil $\mathrm{pH}$ when the soil $\mathrm{pH}$ ranges from 5.0-5.5 [48], so the weak relationship between $\mathrm{Ni}$ and soil $\mathrm{pH}$ may result from the ranges of soil $\mathrm{pH}$ values.
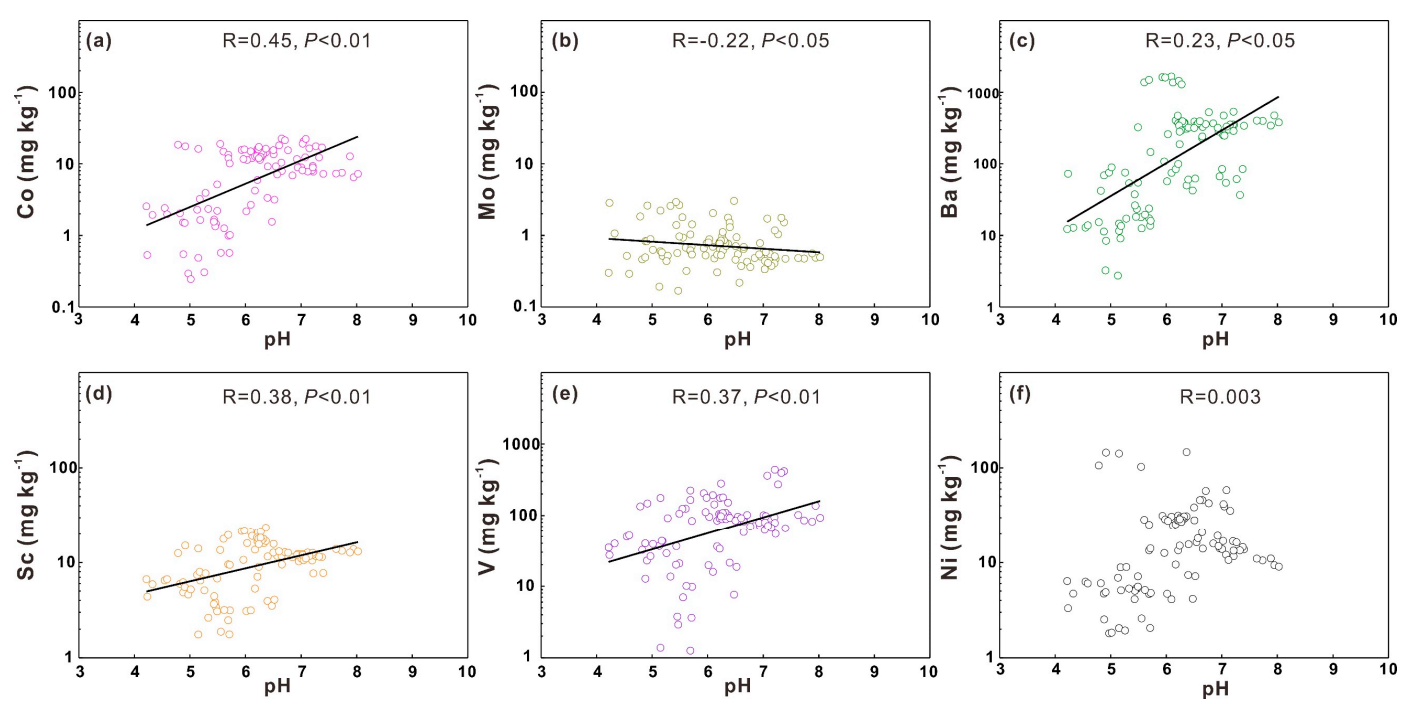

Figure 6. Linear correlation between soil $\mathrm{pH}$ and the heavy metals $\mathrm{Co}(\mathbf{a}), \mathrm{Mo}(\mathbf{b}), \mathrm{Ba}(\mathbf{c}), \mathrm{Sc}(\mathbf{d}), \mathrm{V}(\mathbf{e})$, $\mathrm{Ni}(\mathbf{f})$.

\subsubsection{Influence of Soil Texture on Heavy Metals}

Soil texture is a term used to describe the distributions of soil particle sizes in soils [49]. According to the diameter of soil particles, they can be categorized into three groups: clay, silt and sand. All heavy metals (excluding Mo) are significantly correlated $(P<0.01)$ with clay contents in soils (Figure 7 ), indicating the important role of clay in stabilizing soil heavy metals. Finer soil particles are reported to have a stronger ability to absorb and fix heavy metals on their surface because of their bigger surface area and various functional groups [1,50-52]. Moreover, clay is also found to stabilize soil organic matter that would also fix heavy metals $[13,47]$.

Therefore, the clay benefits the accumulation of soil heavy metals. However, relatively high soil $\mathrm{pH}$ would prevent the adsorption of molybdate by clay [53], which provides a potential explanation for the weak relationship between Mo and clay contents. 

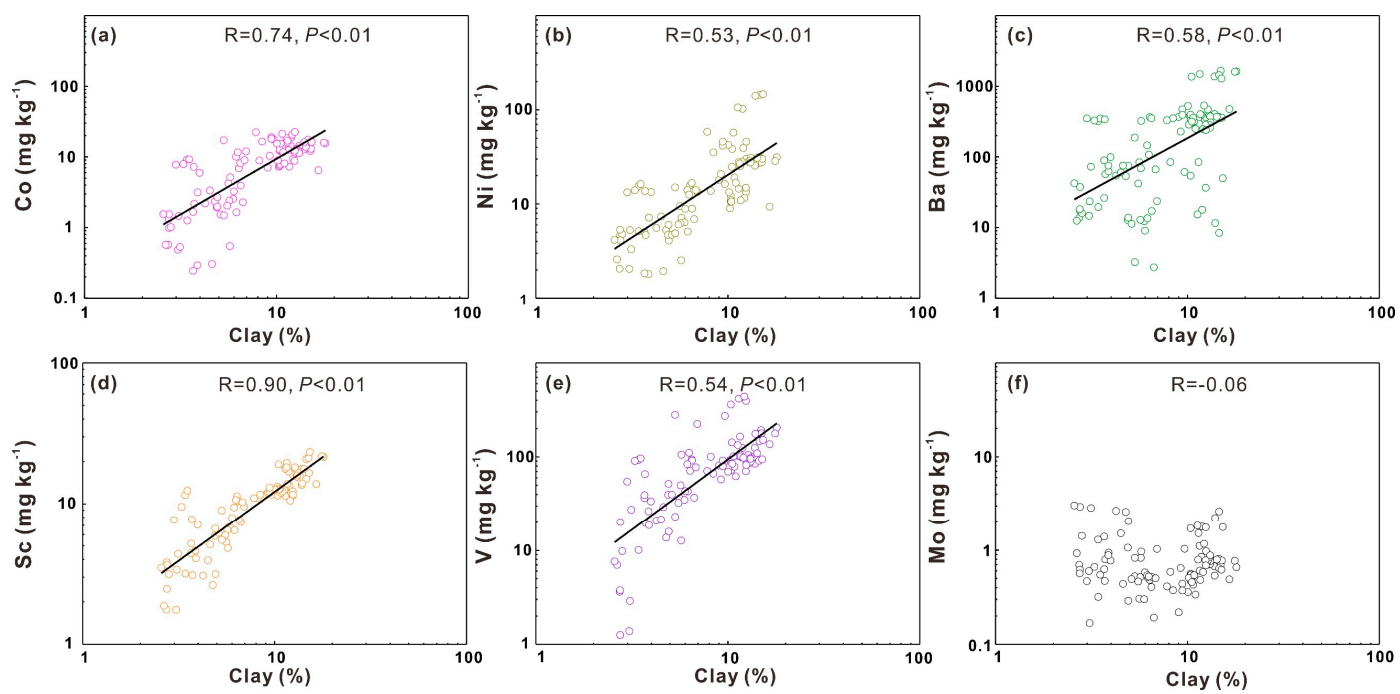

Figure 7. Linear correlation between clay contents and the heavy metals $\mathrm{Co}(\mathbf{a}), \mathrm{Ni}(\mathbf{b}), \mathrm{Ba}(\mathbf{c}), \mathrm{Sc}(\mathbf{d})$, $\mathrm{V}(\mathbf{e}), \operatorname{Mo}(\mathbf{f})$.

\subsection{Principal Component Analysis for Heavy Metals}

Principal component analysis (PCA) is an important multivariate analysis method applied to identify the sources of soil heavy metals [54]. The prerequisite of the application of PCA is to pass the Kaiser-Meyer-Olkin (KMO) and Bartlett's sphericity tests: the KMO measure should be higher than 0.5 and Bartlett's sphericity test should be significant $(P<0.001)[28,55,56]$. The KMO value equals 0.61 and Bartlett's sphericity test is significant $(P=0)$ in this study, indicating that PCA is applicable to the analysis of these soil samples. The results of PCA are presented in Table 4.

Table 4. Principal component analysis (PCA) of heavy metals.

\begin{tabular}{ccc}
\hline \multirow{2}{*}{ Element } & \multicolumn{2}{c}{ Component } \\
\cline { 2 - 3 } & PC1 & PC2 \\
\hline Co & 0.90 & 0.11 \\
$\mathrm{Ni}$ & 0.64 & 0.56 \\
$\mathrm{Mo}$ & -0.05 & 0.85 \\
$\mathrm{Ba}$ & 0.66 & -0.52 \\
$\mathrm{Sc}$ & 0.93 & -0.17 \\
$\mathrm{~V}$ & 0.68 & 0.13 \\
Eigenvalue & 2.98 & 1.36 \\
Variance \% & 49.70 & 22.71 \\
Cumulative \% & 49.70 & 72.41 \\
\hline
\end{tabular}

On condition that eigenvalues are higher than 1, two principal components are extracted which explain $72.41 \%$ of the total variance (PC1: $49.70 \%$; PC2: 22.71\%) (Table 4). As shown in Table 4, PC1 is positively correlated with the heavy metals $\mathrm{Co}, \mathrm{Ni}, \mathrm{Ba}, \mathrm{Sc}$ and $\mathrm{V}$, and $\mathrm{PC} 2$ positively correlates with Mo. Based on the results of PCA, these heavy metals can be categorized into two groups (PC1: Co, Ni, Ba, Sc and V; PC2: Mo). The heavy metals $\mathrm{Co}, \mathrm{Ni}, \mathrm{Sc}$ and $\mathrm{V}$ are usually regarded as lithophile elements that are associated with soil minerals [3,52], while Mo and Ba are regarded as anthropogenic elements [52]. As an important agricultural region, anthropogenic sources in the Mun River Basin should be the application of fertilizers, including chemical fertilizers and organic fertilizers as mentioned before. Therefore, the first factor may refer to soil mineral compositions which are largely determined by the parent rocks and the second factor may refer to the impact of human activities. In this study, only the heavy metal Mo is dominated by the second factor, indicating that soil in the study area is little influenced by the heavy metals $\mathrm{Co}, \mathrm{Ni}, \mathrm{Ba}, \mathrm{Sc}$ and $\mathrm{V}$ derived from anthropogenic activities. Although 
the topsoil seems to be slightly or moderately polluted by these heavy metals due to the application of fertilizers as discussed before, the impact of anthropogenic activities is relatively limited compared with that of natural processes according to the PCA results.

\section{Conclusions}

The soil heavy metal concentrations decrease following the sequence of $\mathrm{Ba}, \mathrm{V}, \mathrm{Ni}, \mathrm{Sc}, \mathrm{Co}$ and Mo in soil profiles T1, T3, T4 and T5; the sequence of Ni, V, Ba, Co, Sc, Mo in soil profile T2; and the sequence of $\mathrm{Ba}, \mathrm{V}, \mathrm{Sc}, \mathrm{Ni}, \mathrm{Mo}, \mathrm{Co}$ in soil profile T6. The EF values of most samples are lower than 1.5 , indicating that these heavy metals are mainly derived from natural processes. The EF values of Mo in paddy fields are lower than 0.5, which provides evidence for the existence of Mo deficiency in the agricultural lands of Northeast Thailand. The application of molybdenum fertilizer should be advocated to eliminate the adverse effect of Mo deficiency on crops. The geoaccumulation index shows that only the topsoil of the soil profiles T1 and T2 is slightly contaminated by the heavy metals Ba, Sc, $\mathrm{Ni}$ and V. Overall, soils in the study area are in relatively good condition. The PCA results reveals that two factors (parent rocks and human activities) are responsible for $72.4 \%$ of the total variations of heavy metals in soil profiles: $\mathrm{Co}, \mathrm{Ni}, \mathrm{Ba}, \mathrm{Sc}$ and $\mathrm{V}$ are dominated by the first factor while Mo is dominated by the second factor. The correlation analysis shows that soil organic matter and clay benefit the accumulation of heavy metals. Soil $\mathrm{pH}$ is positively correlated with heavy metals $\mathrm{Co}, \mathrm{Ba}, \mathrm{Sc}$ and $\mathrm{V}$ but is negatively correlated with Mo, which may result due to Mo usually existing in the form of oxyanions instead of cations like most heavy metals.

Author Contributions: Conceptualization, G.H. and W.Z.; methodology, G.H., M.L., X.L. and C.S.; validation, G.H., M.L. and W.Z.; formal analysis, W.Z.; investigation, G.H., M.L., X.L., C.S., F.M.; resources, G.H.; data curation, W.Z.; writing - original draft preparation, W.Z.; writing-review and editing, G.H.; supervision, G.H.; project administration, G.H.; funding acquisition, G.H. All authors have read and agreed to the published version of the manuscript.

Funding: This research was funded by the National Natural Science Foundation of China (Grant No. 41661144029; 41325010).

Acknowledgments: The authors gratefully acknowledge our teammates from the Ministry of Natural Resource and Environment of Thailand.

Conflicts of Interest: The authors declare no conflict of interest.

\section{References}

1. Rajmohan, N.; Prathapar, S.A.; Jayaprakash, M.; Nagarajan, R. Vertical distribution of heavy metals in soil profile in a seasonally waterlogging agriculture field in Eastern Ganges Basin. Environ. Monit. Assess. 2014, 186, 5411-5427. [CrossRef]

2. Krishna, A.K.; Govil, P.K. Soil contamination due to heavy metals from an industrial area of Surat, Gujarat, Western India. Environ. Monit. Assess. 2007, 124, 263-275. [CrossRef]

3. Li, P.Z.; Lin, C.Y.; Cheng, H.G.; Duan, X.L.; Lei, K. Contamination and health risks of soil heavy metals around a lead/zinc smelter in southwestern China. Ecotox. Environ. Safe. 2015, 113, 391-399. [CrossRef] [PubMed]

4. Tang, Y.; Han, G.L. Characteristics of major elements and heavy metals in atmospheric dust in Beijing, China. J. Geochem. Explor. 2017, 176, 114-119. [CrossRef]

5. Qu, R.; Han, G.; Liu, M.; Li, X. The Mercury Behavior and Contamination in Soil Profiles in Mun River Basin, Northeast Thailand. Int. J. Environ. Res. Public Health 2019, 16, 4131. [CrossRef] [PubMed]

6. Li, X.P.; Feng, L.N. Multivariate and geostatistical analyzes of metals in urban soil of Weinan industrial areas, Northwest of China. Atmos. Environ. 2012, 47, 58-65. [CrossRef]

7. Gomez-Aracena, J.; Martin-Moreno, J.M.; Riemersma, R.A.; Bode, P.; Gutierrez-Bedmar, M.; Gorgojo, L.; Kark, J.D.; Garcia-Rodriguez, A.; Gomez-Gracia, E.; Kardinaal, A.F.M.; et al. Association between toenail scandium levels and risk of acute myocardial infarction in European men: The EURAMIC and Heavy Metals Study. Toxicol. Ind. Health 2002, 18, 353-360. [CrossRef] 
8. Zarcinas, B.A.; Pongsakul, P.; McLaughlin, M.J.; Cozens, G. Heavy metals in soils and crops in southeast Asia. 2. Thailand. Environ. Geochem. Health 2004, 26, 359-371. [CrossRef]

9. Alloway, B.J. Heavy Metals in Soils: Trace Metals and Metalloids in Soils and Their Bioavailability; Springer Science \& Business Media: Berlin/Heidelberg, Germany, 2012; Volume 22.

10. Clarkson, D.T.; Hanson, J.B. The mineral nutrition of higher plants. Annu. Rev. Plant Physiol. 1980, 31, 239-298. [CrossRef]

11. Osotsapar, Y. Micronutrients in crop production in Thailand; Food and Fertilizer Technology Center: Taipei, Taiwan, 2000.

12. Tiaranan, N.; Pimsarn, S.; Claimon, S.; Punpruk, P. Correction of nutrient deficiencies of legumes in Thailand. Trop. Legume Improv. 1985, 8, 54-55.

13. Zeng, F.R.; Ali, S.; Zhang, H.T.; Ouyang, Y.B.; Qiu, B.Y.; Wu, F.B.; Zhang, G.P. The influence of pH and organic matter content in paddy soil on heavy metal availability and their uptake by rice plants. Environ. Pollut. 2011, 159, 84-91. [CrossRef] [PubMed]

14. Wijnhoud, J.D.; Konboon, Y.; Lefroy, R.D.B. Nutrient budgets: Sustainability assessment of rainfed lowland rice-based systems in northeast Thailand. Agric. Ecosyst. Environ. 2003, 100, 119-127. [CrossRef]

15. Floch, P.; Molle, F. Irrigated agriculture and rural change in Northeast Thailand: Reflections on present developments. In Governing the Mekong: Engaging in the Politics of Knowledge; Daniel, R., Lebel, L., Manorom, K., Eds.; Strategic Information and Research Development Centre (SIRD): Petaling Jaya, Malaysia, 2013; pp. 185-198.

16. Khunthasuvon, S.; Rajastasereekul, S.; Hanviriyapant, P.; Romyen, P.; Fukai, S.; Basnayake, J.; Skulkhu, E. Lowland rice improvement in northern and northeast Thailand 1. Effects of fertiliser application and irrigation. Field Crop. Res. 1998, 59, 99-108. [CrossRef]

17. Nimnate, P.; Thitimakorn, T.; Choowong, M.; Hisada, K. Imaging and locating paleo-channels using geophysical data from meandering system of the Mun River, Khorat Plateau, Northeastern Thailand. Open Geosci. 2017, 9, 675-688. [CrossRef]

18. Liu, M.; Han, G.; Zhang, Q. Effects of agricultural abandonment on soil aggregation, soil organic carbon storage and stabilization: Results from observation in a small karst catchment, Southwest China. Agric. Ecosyst. Environ. 2020, 288, 106719. [CrossRef]

19. Han, G.L.; Li, F.S.; Tang, Y. Variations in soil organic carbon contents and isotopic compositions under different land uses in a typical karst area in Southwest China. Geochem. J. 2015, 49, 63-71. [CrossRef]

20. Liu, M.; Han, G.L.; Zhang, Q.; Song, Z.L. Variations and Indications of C-13(SOC) and N-15(SON) in Soil Profiles in Karst Critical Zone Observatory (CZO), Southwest China. Sustainability 2019, 11, 16.

21. Han, G.L.; Li, F.S.; Tang, Y. Organic Matter Impact on Distribution of Rare Earth Elements in Soil Under Different Land Uses. Clean-Soil Air Water 2017, 45, 9. [CrossRef]

22. Zoller, W.H.; Gladney, E.S.; Duce, R.A. Atmospheric concentrations and sources of trace metals at the South pole. Science 1974, 183, 198-200. [CrossRef]

23. Muller, G. Index of geoaccumulation in sediments of the Rhine River. Geojournal 1969, 2, 108-118.

24. Wedepohl, K.H. The composition of the continental-crust. Geochim. Cosmochim. Acta 1995, 59, 1217-1232. [CrossRef]

25. Lu, X.W.; Wang, L.J.; Lei, K.; Huang, J.; Zhai, Y.X. Contamination assessment of copper, lead, zinc, manganese and nickel in street dust of Baoji, NW China. J. Hazard. Mater. 2009, 161, 1058-1062. [CrossRef] [PubMed]

26. Balls, P.; Hull, S.; Miller, B.; Pirie, J.; Proctor, W. Trace metal in Scottish estuarine and coastal sediments. Mar. Pollut. Bull. 1997, 34, 42-50. [CrossRef]

27. Zeng, J.; Han, G.L.; Wu, Q.X.; Tang, Y. Heavy Metals in Suspended Particulate Matter of the Zhujiang River, Southwest China: Contents, Sources, and Health Risks. Int. J. Environ. Res. Public Health 2019, 16, 1843. [CrossRef] [PubMed]

28. Fang, X.H.; Peng, B.; Wang, X.; Song, Z.L.; Zhou, D.X.; Wang, Q.; Qin, Z.L.; Tan, C.Y. Distribution, contamination and source identification of heavy metals in bed sediments from the lower reaches of the Xiangjiang River in Hunan province, China. Sci. Total Environ. 2019, 689, 557-570. [CrossRef] [PubMed]

29. Zhang, Q.; Han, G.L.; Liu, M.; Liang, T. Spatial distribution and controlling factors of heavy metals in soils from Puding Karst Critical Zone Observatory, southwest China. Environ. Earth Sci. 2019, 78, 13. [CrossRef] 
30. Zeng, J.; Yue, F.-J.; Wang, Z.-J.; Wu, Q.; Qin, C.-Q.; Li, S.-L. Quantifying depression trapping effect on rainwater chemical composition during the rainy season in karst agricultural area, southwestern China. Atmos. Environ. 2019, 218, 116998. [CrossRef]

31. Wong, S.C.; Li, X.D.; Zhang, G.; Qi, S.H.; Min, Y.S. Heavy metals in agricultural soils of the Pearl River Delta, South China. Environ. Pollut. 2002, 119, 33-44. [CrossRef]

32. Kabata-Pendias, A.; Pendias, H. Trace Elements in Soils and Plants, 2nd ed.; CRC Press: Boca Raton, FL, USA, 1992.

33. Chao, T.T.; Theobald, P.K. The significance of secondary iron and manganese oxides in geochemical exploration. Econ. Geol. 1976, 71, 1560-1569. [CrossRef]

34. Xu, F.J.; Hu, B.Q.; Yuan, S.Q.; Zhao, Y.F.; Dou, Y.G.; Jiang, Z.Z.; Yin, X.B. Heavy metals in surface sediments of the continental shelf of the South Yellow Sea and East China Sea: Sources, distribution and contamination. Catena 2018, 160, 194-200. [CrossRef]

35. Zhang, J.; Liu, C.L. Riverine composition and estuarine geochemistry of particulate metals in China-Weathering features, anthropogenic impact and chemical fluxes. Estuar. Coast. Shelf Sci. 2002, 54, 1051-1070. [CrossRef]

36. Wong, C.S.C.; Li, X.D.; Thornton, I. Urban environmental geochemistry of trace metals. Environ. Pollut. 2006, 142, 1-16. [CrossRef] [PubMed]

37. Mortvedt, J.J. Heavy metal contaminants in inorganic and organic fertilizers. Fertil. Res. 1996, 43, 55-61. [CrossRef]

38. Yan, X.; Luo, X.G. Heavy Metals in Sediment from Bei Shan River: Distribution, Relationship with Soil Characteristics and Multivariate Assessment of Contamination Sources. Bull. Environ. Contam. Toxicol. 2015, 95, 56-60.

39. Kabata-Pendias, A.; Mukherjee, A.B. Trace Elements From Soil to Human; Springer Science \& Business Media: Berlin/Heidelberg, Germany, 2007.

40. Krishnamurti, G.S.R.; Huang, P.M.; Kozak, L.M. Sorption and desorption kinetics of cadmium from soil: Influence of phosphate. Soil Sci. 1999, 164, 888-898. [CrossRef]

41. Lair, G.J.; Gerzabek, M.H.; Haberhauer, G. Sorption of heavy metals on organic and inorganic soil constituents. Environ. Chem. Lett. 2007, 5, 23-27. [CrossRef]

42. Pribyl, D.W. A critical review of the conventional SOC to SOM conversion factor. Geoderma 2010, 156, 75-83. [CrossRef]

43. Wichard, T.; Mishra, B.; Myneni, S.C.B.; Bellenger, J.P.; Kraepiel, A.M.L. Storage and bioavailability of molybdenum in soils increased by organic matter complexation. Nat. Geosci. 2009, 2, 625-629. [CrossRef]

44. Muhlbachova, G.; Simon, T.; Pechova, M. The availability of $\mathrm{Cd}, \mathrm{Pb}$ and $\mathrm{Zn}$ and their relationships with soil pH and microbial biomass in soils amended by natural clinoptilolite. Plant Soil Environ. 2005, 51, $26-33$. [CrossRef]

45. Chuan, M.C.; Shu, G.Y.; Liu, J.C. Solubility of heavy metals in a contaminated soil: Effects of redox potential and pH. Water Air Soil Pollut. 1996, 90, 543-556. [CrossRef]

46. Zeng, J.; Han, G.; Wu, Q.; Tang, Y. Effects of agricultural alkaline substances on reducing the rainwater acidification: Insight from chemical compositions and calcium isotopes in a karst forests area. Agric. Ecosyst. Environ. 2020, 290, 106782. [CrossRef]

47. Zhou, W.X.; Han, G.L.; Liu, M.; Li, X.Q. Effects of soil pH and texture on soil carbon and nitrogen in soil profiles under different land uses in Mun River Basin, Northeast Thailand. PeerJ 2019, 7, 15. [CrossRef] [PubMed]

48. Blake, L.; Goulding, K.W.T. Effects of atmospheric deposition, soil pH and acidification on heavy metal contents in soils and vegetation of semi-natural ecosystems at Rothamsted Experimental Station, UK. Plant Soil 2002, 240, 235-251. [CrossRef]

49. Dexter, A.R. Soil physical quality-Part I. Theory, effects of soil texture, density, and organic matter, and effects on root growth. Geoderma 2004, 120, 201-214. [CrossRef]

50. Damrongsiri, S.; Vassanadumrongdee, S.; Tanwattana, P. Heavy metal contamination characteristic of soil in WEEE (waste electrical and electronic equipment) dismantling community: A case study of Bangkok, Thailand. Environ. Sci. Pollut. Res. 2016, 23, 17026-17034. [CrossRef] 
51. Yin, Y.J.; Impellitteri, C.A.; You, S.J.; Allen, H.E. The importance of organic matter distribution and extract soil: Solution ratio on the desorption of heavy metals from soils. Sci. Total Environ. 2002, 287, 107-119. [CrossRef]

52. Wang, X.S.; Qin, Y.; Chen, Y.K. Heavy meals in urban roadside soils, part 1: Effect of particle size fractions on heavy metals partitioning. Environ. Geol. 2006, 50, 1061-1066. [CrossRef]

53. McBride, M.B.; Richards, B.K.; Steenhuis, T.; Spiers, G. Molybdenum uptake by forage crops grown on sewage sludge-amended soils in the field and greenhouse. J. Environ. Qual. 2000, 29, 848-854. [CrossRef]

54. Gerdol, R.; Marchesini, R.; Iacumin, P.; Brancaleoni, L. Monitoring temporal trends of air pollution in an urban area using mosses and lichens as biomonitors. Chemosphere 2014, 108, 388-395. [CrossRef]

55. Dahal, H. Factor analysis for soil test data: A methodological approach in environment friendly soil fertility management. J. Agric. Environ. 2007, 8, 8-19. [CrossRef]

56. Han, G.L.; Song, Z.L.; Tang, Y.; Wu, Q.X.; Wang, Z.R. Ca and Sr isotope compositions of rainwater from Guiyang city, Southwest China: Implication for the sources of atmospheric aerosols and their seasonal variations. Atmos. Environ. 2019, 214, 10. [CrossRef]

(C) 2020 by the authors. Licensee MDPI, Basel, Switzerland. This article is an open access article distributed under the terms and conditions of the Creative Commons Attribution (CC BY) license (http://creativecommons.org/licenses/by/4.0/). 